\title{
Fiscal Decentralization and Local Finance Reforms in Bulgaria: A Review of Ten Years' Experience
}

\author{
Assoc.Professor Dr. Presiana Nenkova \\ Department of Finance, University of National and World Economy, Sofia, Bulgaria \\ Email:presiana_n@hotmail.com
}

\section{Doi:10.5901/mjss.2014.v5n23p342}

\begin{abstract}
The changes in the system of intergovernmental fiscal relations in Bulgaria commenced at the beginning of the 1990s with the enactment of legislation on local self-governance and the first timid attempts at an expenditure and revenue assignment between the levels of government. The process began to gather momentum in 2002 when the government adopted a Concept paper on fiscal decentralization and an action plan on its implementation. A number of key reforms were legislated with the aim of broadening the municipal own-sources revenue base and increasing local government revenue autonomy. Dedicated action to set a decentralized public finance system in place resulted in a visible improvement of financial self-sufficiency of local authorities. Although still low in a European context, the values of fiscal decentralization indicators have gradually risen over the years, which is indicative of the success of the reform. The purpose of this paper is to overview the development of the process of fiscal decentralization in Bulgaria in the period 2003-2012 through examining its key aspects - expenditure responsibilities, revenue assignment and intergovernmental transfers - and to assess the policy options for addressing the current problems of local finance system.
\end{abstract}

Keywords: fiscal decentralization, local finance reform, intergovernmental fiscal relations, Bulgaria

\section{Introduction}

Decentralization in Bulgaria was an inevitable part of the process of transformation that took place in all former socialist countries during the 1990s. Despite the significant differences in the degree of decentralization and the progress achieved, transition economies shared a common feature in that "they began from a legacy of a highly-centralized system of public finances with subnational governments acting mainly as administrative units with little independent fiscal responsibilities" (Dabla-Norris, 2006, p.104). This legacy together with macroeconomic instability put serious obstacles in front of implemented decentralization initiatives. Several studies demonstrated that public finance system decentralization in transition economies went hand in hand with delegating greater responsibilities to local authorities in terms of public service provision without adequate financial backing of this process or ensuring that local governments had real decisionmaking power (Olivera and Martinez-Vazquez, 2001; Rodriguez-Pose and Kroijer, 2009; Wetzel, 2001).

Bulgaria was not an exception to the rule and devolving more revenue autonomy to local governments encountered serious delays. Along with the fundamental changes in the economy, processes of territorial restructuring and devolution of responsibilities to local governments were commenced in 1991. The territory of Bulgaria - a unitary state, was divided into 28 provinces and 264 municipalities. Provinces were not granted financial independence and continue to operate as representative administrative bodies of the central government. The 264 municipalities are the only tier of subnational government in Bulgaria. During this period a series of laws addressing issues such as local selfgovernance, local elections, independence of local government budgets, municipal ownership and subnational revenue sources were enacted.

Although attempts were made to clearly differentiate between the responsibilities of the two levels of government, there remained contradictory legislation governing the functions and tasks of local governments in certain areas. The frequent changes in the responsibilities vested in municipalities was a serious setback and created a significant hurdle in budget planning, along with the fact that local governments had little discretion in terms of service provision (Bird, Ebel and Wallich, 1995). At the same time, almost no action was concurrently taken to increase local government own revenue base and municipalities continued to rely heavily on intergovernmental transfers and shared tax. In addition, the lack of a transparent system of intergovernmental transfers and their preliminary gap filling character influenced negatively municipal revenues mobilization.

The actual fiscal decentralization in Bulgaria commenced in earnest in 2002 with the adoption by the government 
of a Concept paper on fiscal decentralization and an action plan on its implementation. The purpose of 2002 reform package was to clearly define the responsibilities of municipalities and identify the sources of their financing, create sound and rules-based system of intergovernmental transfers and strengthen the financial capacity of local authorities. Over the last ten years significant efforts have been made to successfully reform the intergovernmental fiscal relations in Bulgaria but there are still many issues to be addressed. The objective of current paper is to provide an assessment of reforms undertaken with suggestions concerning unresolved problems. The paper is organized as follow. The next section briefly presents the importance of local governments in Bulgaria. The focus of section 3 and section 4 is on local government functions and the key challenges of their financing. Section 5 critically reviews the system of intergovernmental transfers and paper concludes with some policy implications.

\section{A Brief Overview of Local Public Sector Importance}

The importance of local governments in Bulgaria is assessed by using two indicators - share of total public sector expenditure and local government expenditure as a percentage of GDP. Between 2004 and 2008 there was an increase in the share of local government expenditure in GDP and total public expenditure whilst at the same time the share of central government expenditure in GDP constantly decreased and its activities were scaling back (Figure 1). Despite the increasing importance of local public sector in the economy and rising weight of local expenditure in total public spending, Bulgarian public sector remains relatively centralized. In expenditure terms, the weight of local governments reaches its peak of about one-fourth that of the central government in 2008. During that year about $20.5 \%$ of total public spending was undertaken at local level and the expenditure/GDP ratio stood at 7.6\%. Both ratios were below the corresponding EU average of $27.5 \%$ and $12.9 \%$ respectively. (CEMR - Dexia, 2009).

Figure 1. Spending shares of central and local governments in Bulgaria (2003-2012)

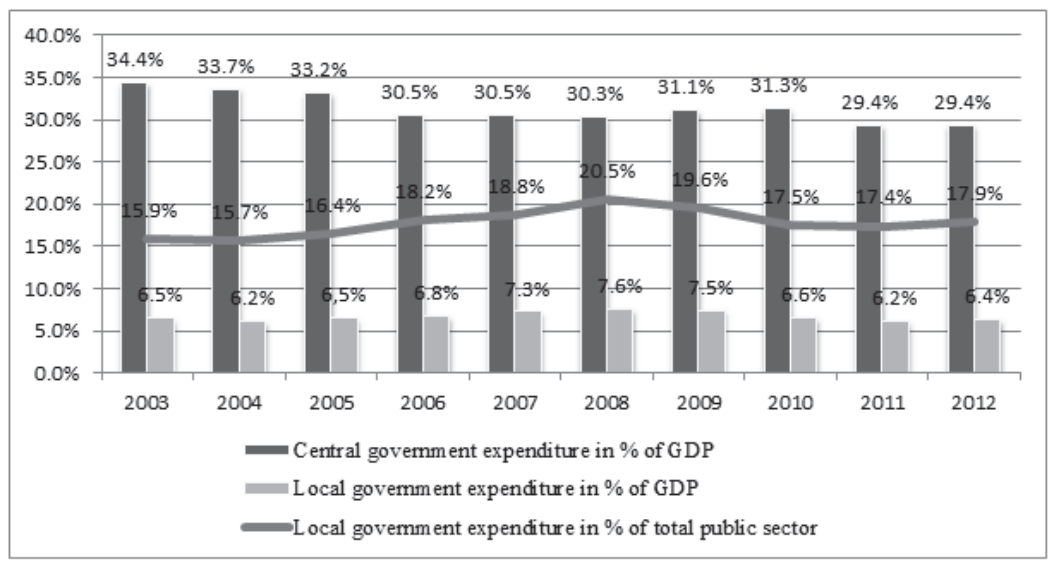

Source: Data on the Consolidated Fiscal Program (Annual), Ministry of Finance of the Republic of Bulgaria; author's calculations

Between 2009 and 2011 a trend of decreasing local expenditure as a share of GDP and in total public sector became clearly visible. The decrease was a natural result of the economic slump that followed the global financial and economic crisis. European funds, an important source of financing capital investment projects were the only counterweight to spending cuts, especially severe in 2010 when expenditure recorded drop of over 9\%, and indeed had a positive effect on the values of decentralization indicators. If expenditure financed from this source is excluded, the indicator of share of local expenditure in GDP in 2012 would stand at $5.3 \%$ and that of their share in total public sector at 15\%, respectively.

\section{Local Government Expenditure Responsibilities}

The scope of the responsibilities of local governments in Bulgaria is stipulated in the Local Self-Governance and Local Authorities Act. These include, inter alia, territorial planning and development, education, healthcare, culture, social services, public works and utilities, sports, recreation and tourism. At the same time, the law does not distinguish between 
activities that are purely own responsibilities of local governments and those delegated by the state or between mandatory responsibilities and public services provided at the discretion of local governments.

One of the most significant changes legislated in 2002 as part of the fiscal decentralization programme was the separation of local services funded from the municipal budgets into two categories - local and delegated - with the aim of drawing a clear line of distinction between them in terms of the source of financing. The range of delegated activities and the standard for their valuation and quantitative appraisal is determined annually by a decision adopted by the Council of Ministers.

Local activities dominate in the area of municipal housing, public works and utility and economic services, with municipalities having a clear mandate to independently determine their type, scope and quality. They are financed up to the level of local government own revenue and the general equalizing grant. Delegated activities dominate in the area of education, healthcare, social assistance and culture. The necessary financial resources to supply these services are transferred to municipal budgets through a separate conditional grant.

The distinction between the services supplied by municipalities on the basis of the source of financing does not substitute the lack of clearly defined rules on the scope of activities that are purely local in nature or, alternatively ones that are considered a national priority or have significant benefit spill overs and should therefore be treated as delegated services provided at local level. Nevertheless, thus defined, the scope of local government responsibilities largely reflects the principles of expenditure assignment across levels of governments, outlined in the fiscal federalism studies (MartinezVazquez, 2001; Shah, 1994). For example, devolution of responsibilities to municipalities to deliver a public service providing benefits alongside the entire territory of a country or forming a part of stabilization and redistributive functions is not recommended. The practice in Bulgaria does not contradict these considerations and the central government retains exclusive power over areas such as foreign policy, public order and security, defence, higher education, fiscal policy, social transfers and national roads.

Central financing of delegated services is intended to cover only current expenses and its amount is calculated on the base of uniform costing standards. In fact centrally determined funding for delegated services does not impose "expenditure dictates" (McCullough, Savov\& Ivanov, 2003). Indeed, delegated activities standards ensure an equal financial opportunity for local governments to provide a minimum level of basic public goods for the population, regardless where one lives.

Municipalities are typically dissatisfied with the standards for delegated services, claiming that funding, respectively the grant is too low. Each local council may adopt a decision assigning additional funding from its own revenue to the provision of delegated services, i.e. municipalities can independently decide the level of public service delivery according to local preference and within the confines of their budgets. Thus, the level of own revenue is decisive for additional financing of delegated services above the central one and for the adequate level of local services provided by each municipality. Furthermore, capital expenditure, both in terms of local and delegated activities, are also to be covered from the own revenue of local authorities and specific capital expenditure grant.

Delegated responsibilities generally play a significant role in municipal budgets - their share stood at nearly $50 \%$ of total municipal spending in 2012 (Figure 2). The ratio of expenditure for local responsibilities to total local expenditure was more than $55 \%$ in 2007 but fell to $47 \%$ in 2012. In a situation of rapidly decreasing own revenue (see Figure 4) municipalities are cutting back on local activities and additional funds on the provision of delegated activities beyond and above those received from the central government to cover the minimum standards. 
Figure 2. Breakdown of local government expenditure by function and type of responsibility

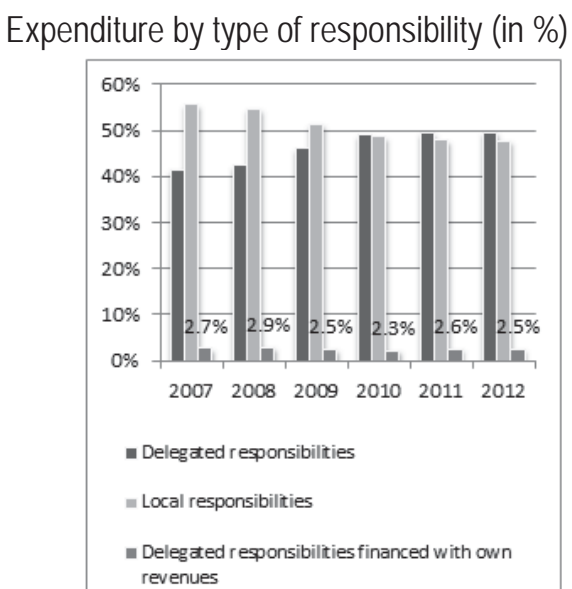

\section{Expenditure by type of function, 2012 (in \%)}

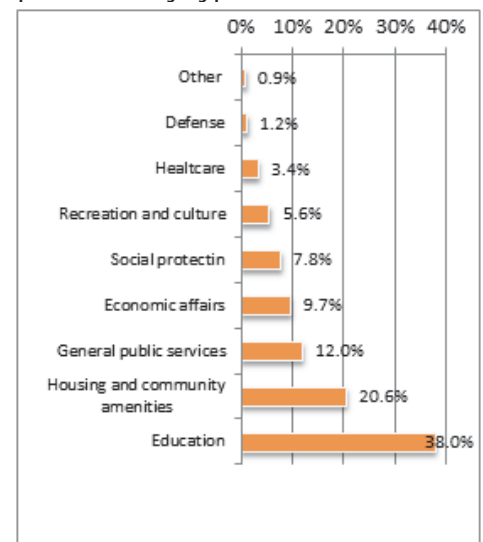

Source: Adapted from National Association of Municipalities in the Republic of Bulgaria, 2014, p.27, annex table 2 and annex table 5

The composition of local government expenditure by function points out the leading position of education with weight of $38 \%$. All activities in the area of pre-school education, early, primary and secondary education are funded from the municipal budget. The main part of education spending, which is highly labour-intensive, are covered by the State, which provides the funds for the delegated activities including salaries and social insurance contributions, school supplies via a grant. Construction and upkeep of buildings, canteens and extra-curricular activities are financed with municipal own revenue. Approximately $30 \%$ of local spending covers activities that are fully within the remit of competence of local governments - housing, community amenities and economic affairs. The third biggest item of spending that on general public accounts for 12 per cent. Social protection and health care are exclusively central government responsibilities and their share in local expenditure is quite small. Municipal budgets finance also municipal hospitals, nursery schools and school surgeries, centres for homeless children, home-based assistance services for the elderly, residential homes for senior citizens and public canteens.

The level of municipal investment and the role of local authorities in total public sector investments in Bulgaria show significant differences as compared to the prevailing EU pattern. Over a significant period of time local government capital expenditure were treated as a low priority and current expenditure had the highest share in the municipal budgets. Since 2005 a positive trend of increase in the level of municipal investment commenced and in 2006 exceeded 20\% for the first time, reaching 29\% of total local expenditure in 2008 (Figure 3). However, the share of Bulgarian municipalities in public sector investment remains at a significantly lower level than EU average of 61.8\% (CEMR - Dexia, 2010). In most countries in Europe, the bulk of public sector investments are implemented at local level. For instance, in 2009 local government capital expenditure share in total public sector was lower than that in Bulgaria in 4 countries only.

Figure 3. Weight of local government capital expenditure

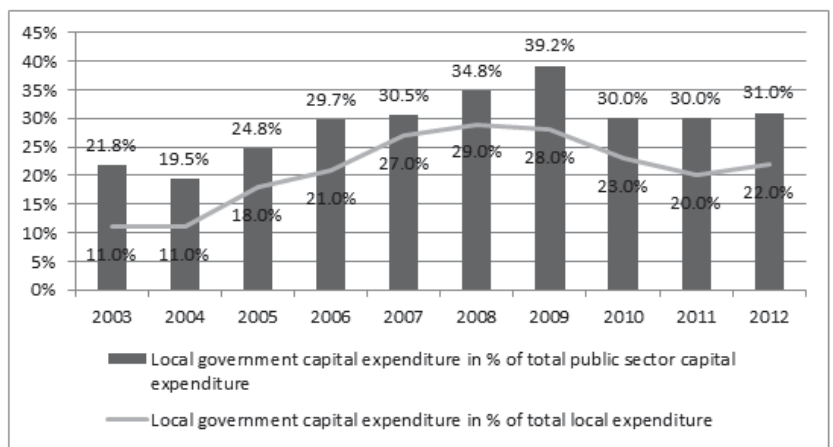

Source: Data on the Consolidated Fiscal Program (Annual), Ministry of Finance of the Republic of Bulgaria; author's calculations 
In 2009, the trend was again reversed with most of municipal funds shifting to current expenditure and the level of local investments plummeting. The decrease of local government own revenue and the dramatic reduction of the capital expenditure grant influenced negatively local government capital expenditure. In recent years, municipalities were able to implement a number of capital investment projects as beneficiaries of different Operational Programmes financed by the EU Structural and Cohesion Funds. For example, in 2012, funds absorbed enabled municipalities to spend BGN 615.2 million for capital expenditure, accounting for more than $40 \%$ of all local level investment. (Ministry of Finance, 2013).

\section{Local Government Own-Sources Revenue}

One of the leading challenges in the context of fiscal decentralization policy in transition economies is granting real autonomy to local authorities (Dabla-Norris and Wade, 2002). In Bulgaria, prior to the start of the reform shared tax revenue and grants had the largest relative share in municipal budgets, with sharing rates being annually changed by the central government and transfers, usually determined on ad hoc base. According to the indicator sets of OECD on tax autonomy (Blöchliger and Rabesona, 2009) local taxes in Bulgaria fell into category "e", representing non-existent tax autonomy since local authorities had no power over rates and bases of local taxes at all. In 2002 less than $15 \%$ of total municipal revenue was under the control of local governments.

From the beginning of 2003, a number of steps have been taken to increase local government revenue base, as well as to provide local authorities with effective revenue decision-making power. As a result there has been a strong growth in own - sources revenue, which peaked in 2008 in nominal terms (Figure 4)

Figure 4. Local government own-sources revenue structure (BGN millions)

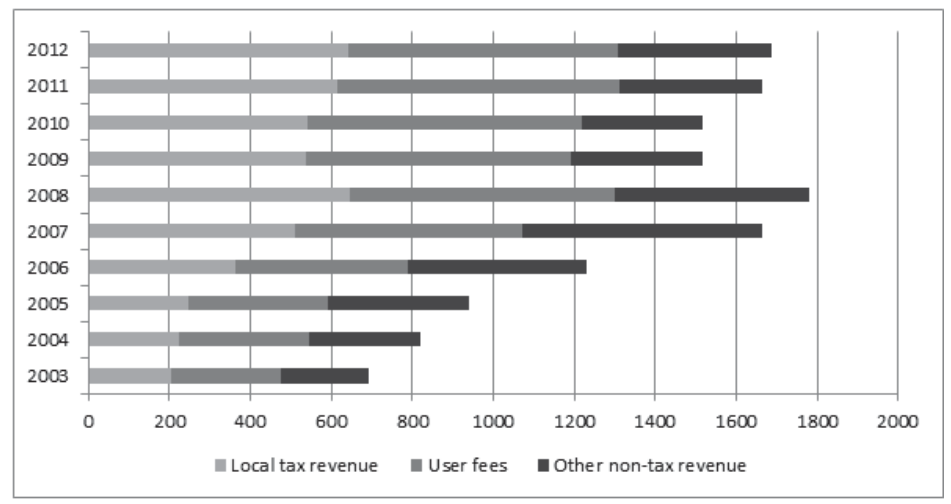

Source: Based on Data on the Consolidated Fiscal Program (Annual) and Reports on the State Budget Execution (20032012), Ministry of Finance of the Republic of Bulgaria

Income from user fees is the largest own-sources revenue for local governments in Bulgaria. Together with other non-tax revenue they account for more than $60 \%$ of municipal own revenue. In accordance with the law, municipalities charge fees for waste collection, the use of of nursery homes, kindergartens, social care homes, camps, hostels and other municipal social services, the use of markets, marketplaces, fairs, sidewalks, and roadbeds, administrative services, technical services, quarry extraction, dog ownership and the purchase of graveyard plots. In addition to these fees, local councils may determine prices for other services provided to local residents. Since 2003 local authorities have had full discretion over fees, notably they were granted independent decision-making powers with regard to the services, once free of charge, to be provided against payment, the rates of the fees and any fee waivers for certain categories of users and also fees revenue collection. In fact, this was the beginning of revenue decentralization, which transformed fees into an important source of local revenue.

One of the most dynamic own-sources revenue for municipalities is the sale and management of municipal property, fines, penalty charges, donations and other non-tax revenue. The sale of property is an attractive option as a source of significant, albeit, one-off income. Indeed, over the years local governments have largely sold property in order to balance their cash flows, which is the reason underlying the significant increase in this type of non-tax municipal revenue. However, the accelerated sale of property does not tie in with an optimal long-term solution and in fact resulted in the depletion of this source of revenue and decrease in yields from municipal property. In addition property revenue 
was hardly hit by the crisis. In 2011 a slight increase was registered in non-tax revenue due to improved rate of collection of fines and penalty charges.

In 2003, as a result of the reform all types of shared tax revenues or local surcharges on national taxes were removed. Municipalities generate tax revenue only from local taxes. These include property tax, inheritance tax, property transactions tax, vehicle tax, patent tax and tourist tax.

Figure 5. Structure of local tax revenues (BGN millions)

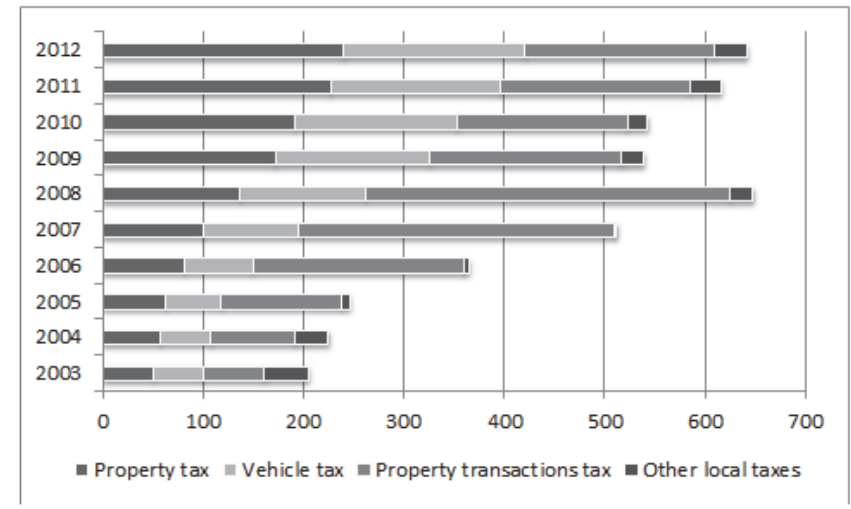

Source: Based on data from Reports on the State Budget Execution (2003-2012), Ministry of Finance of the Republic of Bulgaria

Receipts from property tax, property transactions tax and vehicle tax sum up to $95 \%$ of local tax revenue. Inheritance tax yield is insignificant and patent and tourist tax receipts combined account for less than $5 \%$ of local tax revenue. Until 2005, road tax had a significant share in local tax revenue but it was abolished following the introduction of road vignettes.

The growth in local tax revenue (Figure 5) can be explained by the implementation of two comprehensive local finance reforms. In 2006 local governments were assigned tax collecting responsibility and the great efforts given to the improvement of the collection rate have brought a substantial revenue increase. The powers granted to the municipalities in 2008 to set local tax rates in up and down limits, stipulated by law, has also had a positive impact on the dynamics of tax revenue. At the beginning the difference between the lowest and highest possible tax rates was negligible and failed to produce any significant changes in the tax burden in the different municipalities. In the subsequent years, however, after a few amendments to the Local Taxes and Fees Act, this difference expanded which created conditions for pursuing a more active tax policy at local level.

Property tax is a traditional source of local revenue because it has "immovable" tax base and enables taxation in accordance with the benefit principle (Bird and Slack, 2005; Tanzi, 2001). In Bulgaria, it is levied by local authorities on building and land plots situated within the boundaries of agglomerations where construction is allowed. In most countries property tax revenue is relatively low and rarely exceeds more than 2\% of GDP. By way of comparison, in Bulgaria property tax receipts account for $0.5 \%$ of GDP (European Commission, 2012).

Despite its comparatively low yields potential, property tax provides stable revenue insensitive to fluctuation in economic activity. The tax base is a normative assessment made by local tax administrations by taking into account various features of the property, such as its size, location, structural characteristics, any improvements, last date of repairs etc. Naturally, taxing statutory values can potentially erode the tax base, if not regularly reassessed. The update of statutory values in 2006, following a long delay, has been a major step in bringing them more in with the significant increase in market values during a period of economic growth and in fact explains the higher stream of property tax revenue. Receipts from property tax have been steadily growing. This continuing trend was the result of an increase of the coefficient for location in 2009, which put up statutory values, the raise of top tax brackets (almost twice in 2011) and the enlargement of taxable base.

Another important property related tax is property transactions tax, although its revenue proved to be highly vulnerable. The economic activity on the real estate market and the high volume of real properties sales caused a significant increase in property transactions tax receipts after 2005. The onset of the crisis marked the beginning in this 
tax revenue decrease with a slight increase in 2011 but receipts remaining twice lower than that collected in 2008.

Yet another local tax with a significant contribution to municipal budgets is the vehicle tax. Over the years a stable trends towards an increase of revenue from it has been registered due to the raise of tax rates, the diminishing number of tax reliefs and the efforts of the municipal administrations to improve collection rates. The tax is levied on motor vehicles registered and authorised to use the road network, the ships entered into the record kept by Bulgarian ports and the airplanes entered into the records of aircraft used in civil aviation.

In 2008, as part of the measures intended to expand the revenue base at local level, patent tax was transferred to municipalities. This tax is an alternative to the income tax and is levied in a lump-sum on individuals, including sole traders, carrying out an activity subject to patent tax in the territory of the municipality, provided that the turnover in the previous year does not exceed BGN 50 thousand. The tax has a very narrow scope of application - it is not levied on all enterprises in the jurisdiction of the municipality but only on small businesses engaged in one of the activities exhaustively stipulated in the law, such as sewing services, shoe repairs, hairdressing, cosmetic studios, clock repairs, upholstering businesses, car repairs etc. It limits the revenue potential of patent tax and effectively makes it the least important local tax in Bulgaria.

The positive effects of revenue decentralization in Bulgaria cannot be fully distinguished. A growing share of ownsources revenue in municipal budgets is observed until 2008, but under the influence of the crisis in 2009 municipalities lost a significant part of their receipts - largely from property transactions tax and municipal property sales. In 2010, the relative share of own revenue in municipal budgets increased again despite the lack of changes in terms of their total amount (see Figure 4) due to a cutback in government transfers with more than BGN 300 million. The increase in own revenue in absolute terms in 2012 was marginal but its share in municipal budgets decreased due to the sharp raise of the share of transfers, as a result of the utilization of EU funds.

Figure 6. Own revenue shares of local governments in Bulgaria (2003-2012)

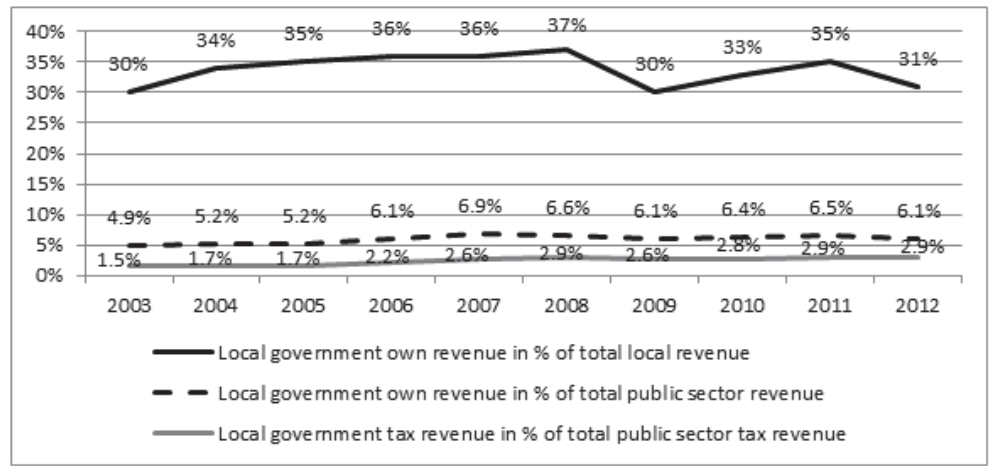

Source: Data on the Consolidated Fiscal Program (Annual), Ministry of Finance of the Republic of Bulgaria; author's calculations

In general terms, despite the higher weight of own-sources revenue, the possibilities available to local governments to fund public service delivery with locally accumulated resources remain limited and over the years about $67 \%$ of municipal financing came from the central government transfers. As observed above (see Figure 1) after the start of the reform municipal expenditures increased significantly to reach $20.5 \%$ от total public sector in 2008. During the same year local own revenue share accounted for only $6.6 \%$ of total public revenue (see Figure 6 ), which reveals the highly centralised nature of public sector revenue system and the low local government revenue raising capacity.

At present, municipal budgets do not receive any revenue from taxes with high yields potential as those levied on household incomes, corporate profits or consumption. Despite of the steps taken to devolve revenue autonomy to local authorities through granting them powers to set and change rates of local taxes within certain brackets, the share of local tax revenue stands at a mere $2.9 \%$ of total public sector tax revenue. Most local authorities are using the possibilities available to them to raise tax rates, although they rarely resort to setting them at levels that are close to the maximum ones permitted by law. At the same time, in some municipalities the tax burden remains closer to that before the changes were introduced, i.e. close to the levels in 2007 , since raising local tax rates is largely regarded as an unpopular political decision (Nikolova et al., 2013). 


\section{Intergovernmental Fiscal Transfers}

There are a number of arguments that justify the economic rationale of central transfers. They can be granted in order to achieve different goals, such as to bridge fiscal gaps, to reduce regional disparities, to set national minimum standards, to enhance benefit spill overs, to influence local priorities, and to serve for stabilization purposes of central government. (Ahmad and Craig, 1997; Bahl and Linn, 1994; Boadway and Hobson, 1993; Shah, 1991).

The main objective of grant design in Bulgaria before 2003 was to compensate municipalities for their insufficient own revenues. One of the transfers also had equalizing functions insofar as it was distributed by formula, which supposedly objectively accounted for each municipalities expenditure needs. Over time, the attempts to modify the formula to ensure that it takes into account all specifics needs of municipalities have resulted in allocation procedures that were extremely complicated, difficult to implement and fully known to few (Ivanov, 1999). The decisions on the total amount of grants, both the general-purpose formula-driven one and the specific-purpose transfers intended to fund social assistance and investments, were taken by the central government on a discretionary basis. The non-transparent manner in which the total pool of grants were being determined and distributed during the period in question, has left the impression of the existence of a group of 'favoured' municipalities, producing negative incentives for revenue mobilization.

In 2003, a new system of intergovernmental transfers was introduced, which comprises three elements - general grant for delegated activities, general equalizing grant and targeted capital expenditure grant. The first element provides financing to cover expenditure for the delivery of state delegated activities. The amount of expenditure is calculated in accordance with the established costing standards and natural indicators, such as personnel number, population size or number of students attending municipal schools. The natural indicators serve also as criteria for the allotment of funds between municipalities. Delegated activities standards are set up in conducted on annual basis negotiations between the national association of municipalities and the central government. In practice central budget constraints often enforce imposing of spending ceilings to definite delegated activities which respectively determines the size of costing standards and the corresponding level of financing.

The total pool of the general equalizing grant is determined by a rule laid down in statute The minimum amount of that grant cannot be lower than $10 \%$ of the figure shown in the report on own revenues of all municipalities for the previous year. Municipalities have full discretion as to the manner in which the transferred funds are spent. The aim of the subsidy is also stipulated by law - to ensure that each municipality achieves a 'minimum level' of local service provision.

Element A1 of the equalizing grants takes into account the spending needs of municipalities by introducing standards for two types of services - childcare facilities and home-based assistance to the elderly. The spending standard is determined in a total sum per child and per assisted person, and covers only $43 \%$ of children under the age of 5 years and 3\% of elderly people aged 65 plus years in the territory of the respective municipality. Full access to this element of the transfer is granted to municipalities whose current expenditure on local services per resident (excluding salaries and social insurance contributions, as well as expenses for waste disposal activities) are lower than the national average per capita.

Element A2, designed to fill to some extend the gap between a municipality's fiscal capacity and the mean across the country, is available to municipalities whose revenue from local taxes is below the national average per capita. The individual allotment is determinate as the amount equal to the difference between the national average and tax revenue per capita in a given municipality is multiplied by the number of residents and corrected with a prescribed coefficient stipulated in the annual State Budget Act. In addition, the equalization entitlement received is adjusted downward for municipalities that have not made a maximum tax effort. The tax effort of a municipality is defined as the average ratio between the rates of property tax and property transactions tax applied previous year and the maximum rates envisaged by law. The higher the tax effort, i.e. the closer the tax effort is to the maximum rate of 1, the larger the equalising subsidy the municipality will receive under this heading.

The equalizing grant comprises yet another component, which aims to guarantee that local governments will have a grant at least equal to the amount of the equalizing grant stipulated in the State Budget Act for the previous year. This part of the subsidy is granted to municipalities with a shortfall between the sum of the elements A1 and A2 (A1+A2) and the amount of the equalizing grant for the previous year. Since 2007, along with the equalizing grant municipalities have been receiving funds for snow clearing and road maintenance during the winter.

The targeted grant for capital expenditures is the least regulated, since there are no strict rules for determining the total pool of funds and the decision about its amount is taken annually by the central government. The allocation rule was first regulated in 2007 and depends on three natural indicators - size of the population, number of agglomerations and territory in a ratio of 40:40:20. The total amount of the grant is distributed on the basis of the relative share of the 
municipality to the country total in terms of the three elements. The capital expenditures grant can be disbursed on both delegated and local activities. Since 2007 a part of this grant is intended to cover the construction and repairs of municipal roads and the distribution of funds depends on the share of each municipality's roads length in total municipal roads network length.

The new system of intergovernmental fiscal transfers has a number of advantages as compared to the one applied until 2003. It ensures greater clarity and transparency in grants design. The general equalizing grant is intended to provide unconditional financial aid to municipalities to meet certain expenditures needs and to equalize their fiscal capacity. Through the delegated activities grant municipalities are expected to achieve a minimum national standard with regard to a certain range of services. However, it is difficult to say that there are no discretionary subsidies since each year the central government decides on the amount of capital expenditures grant. On the other hand, the allocation criteria of the equalizing grant and capital expenditures grant could be changed annually although consulted with the national association of municipalities prior to being enacted as an annex to the State Budget Act for the respective year.

Overall, transfers are the major component of Bulgarian municipal revenue (Figure 6). The main reason for the dominant share of transfers is the tax base centralization, which has resulted in local tax revenue accounting for a mere $2.9 \%$ of consolidated tax revenue. The only option when the central government has a higher position in terms of revenue raising power is to heavy subsidies local governments to overcome the mismatch between local financial resources and local expenditure (Bahl, 2000). However, such a structure of municipal revenue makes local authorities strongly dependent on the availability of the central government funds. For example, in many EU countries there was a reduction in capital or operating transfers to local governments as a result of the central government budget cuts and attempts to create fiscal space to deal with the crisis (CEMR-Dexia, 2012). In Bulgaria, the capital expenditure grant for 2010 stood at BGN 138 million, i.e. almost two times lower than in the previous year (BGN 391 million).

The earmarked to non-earmarked grants ratio is one of the indicators of the degree of financial autonomy of local governments - the lower the weight of earmarked transfers the higher the local government autonomy (Blöchliger and King, 2006). Both earmarked and non-earmarked grants play an important role in the fiscal transfers system. Unconditional transfers are a preferred tool of addressing vertical fiscal imbalances or mitigating the horizontal disparities between jurisdictions. Earmarked transfers are a preferred instrument when the central government wishes to stimulate local governments to provide public services with significant benefits spill overs or when responsibility has been delegated to local governments to provide certain services in line with a set of minimum national standards. Regardless of how the fiscal transfers system will be structured, non-earmarked grants will remain a guarantee for the financial autonomy of local governments, giving them greater freedom in the disbursement of the funds received. (Shah and Gamkhar et all., 2007). It is interesting to note that the ratio between earmarked and non-earmarked grants in Bulgaria changed dramatically after 2002 in favour of conditional transfers, which exceed $90 \%$ of the total transfers to municipalities. The general grant for delegated activities, despite its name, is a specific-purpose grant inasmuch as it is intended to cover certain expenditure - delegated activities current expenditure. To the category of earmarked for specific purposes subsidies belong also the conditional capital expenditures grant, snow cleaning and all the other minor subsidies granted from the sectorial ministries. The general equalizing grant is the only one belonging to the group of unconditional transfers.

\section{Conclusion and Policy Implications}

Since 2003 many steps have been taken and a significant progress has been made toward public sector decentralization in Bulgaria. Expenditure responsibilities have been clearly assigned to different levels of government in accordance to their sources of financing. As a whole the system of intergovernmental transfer system appeared to become more transparent and there has been a significant improvement in the design of general equalization grant. Local governments were given the right to determine tax rates in up and down limits set by law. The general effect of the reform undertaken was strengthening the fiscal positions of local governments in Bulgaria and increasing their role in the economy.

However, there are still unresolved problems. Although local government were granted greater revenue autonomy decentralization of revenue sources is still a big challenge. Local public services provision in Bulgaria is financed primary by earmarked grants, followed by consumer fees and non-tax revenues. Insofar as the tax revenues entering in the local budget accounts for only $2.9 \%$ of the consolidated tax revenues, the restructuring of national tax system would be essential for improving the general adequacy of the local revenue base. One possibility available is to allow local governments to levy surcharges on the central government taxes or to allow them to receive a share of personal income tax or corporate income tax receipts according to the derivation approach. There is also an additional potential for increasing revenues from local taxes. It is possible through enlarging local property tax base or replacing the patent tax 
with a local business levy, due by all enterprises and based on their operating profits, added value or payroll. This will inevitably result in a great burden for taxpayers as compared to the option of attributing a part of the central government tax yields to local authorities. On the other hand, the greater share of own revenue in the budgets of local authorities, particularly from local taxes will create incentives for more responsible spending of public funds and is a prerequisite for pursuing a fiscal policy that is in line with the preferences of local residents.

Yet another challenge that has not been addressed is the stability of the system of fiscal transfers and the application of rules for the calculation of the total amount of capital expenditure grant, which give local governments security that revenue flows, will not fluctuate on an annual basis. As regards the delegated activities grant, their financing should be planned on account of special rules for updating or modifying spending standards or adjusting them with the rate of inflation. In addition, the spending standards for delegated activities cover only operational expenses and municipalities are responsible for covering capital expenditures of both delegated and local activities. Insofar as in recent years delegated activities account for nearly fifty percent of local government spending, the central government should take responsibility for the funding of both operational costs and capital investments. In turn, this presupposes a significant increase of the total pool of the capital expenditure grant and a rethinking of the manner in which its amount is allocated between municipalities.

\section{References}

Ahmad, E. and Craig,J. (1997). Intergovernmental transfers. In T. Ter- Minassian (Ed.), Fiscal Federalism in Theory and Practice (pp.73107). Washington, D.C.: International Monetary Fund (IMF).

Bahl, R. (2000). Intergovernmental Transfers in Developing and Transitional Countries: Principles and Practice. Washington, D.C.: The World Bank.

Bahl, R. and Linn,J. (1994). Fiscal Decentralization and Intergovernmental Transfers in Less Developed Countries, Publius: The Journal of Federalism, 24, pp. 1-19.

Bird, R., Ebel, R. and Wallich, C. (1995). Fiscal Decentralization : from command to market. In Bird, R., Ebel, R. and Wallich, C. (eds.) Decentralization of the Socialist States: Intergovernmental Finance in Transitional Economies, p.1-68, Washington, D.C.:World Bank.http://dx.doi.org/10.1596/0-8213-3186-8

Bird, R. and Slack,E. (2005). Land and Property Taxation in 25 Countries: A Comparative Review. Research Reports, CESifo Dice Report, 3/2005.

Blöchliger, H. and King,D. (2006). Fiscal Autonomy of Sub-Central Governments. OECD Working Papers on Fiscal Federalism, No. 2, OECD Publishing.http://dx.doi.org/10.1787/5k97b127pc0t-en

Blöchliger, H. and Rabesona,J. (2009). Fiscal Autonomy of Sub-Central Governments: An Update. OECD Working Papers on Fiscal Federalism, No. 9, OECD Publishing.http://dx.doi.org/10.1787/5k97b111wbot-en

Boadway, R. and Hobson,A. (1993). Intergovernmental Fiscal Relations in Canada. Canadian Tax Paper 96, Ottawa: Canadian Tax Foundation.

Council of European Municipalities and Regions - Dexia. (2009). EU sub-national Governments: 2008 Key Figures. 2009/2010 edition. Brussels, CEMR. [Online] Available: http://www.ccre.org/docs/nuancier_2009_en.pdf (24 June, 2014)

Council of European Municipalities and Regions - Dexia. (2010). EU sub-national Governments: 2009 Key Figures.

2010/2011 edition. Brussels, CEMR. [Online] Available: http://www.ccre.org/docs/chiffres_cles_2010_UK_bd.pdf (13 June, 2014)

Council of European Municipalities and Regions - Dexia. (2012). Subnational public finance in the European Union. Summer 2012. 11 ${ }^{\text {th }}$ edition. Brussels, CEMR. [Online] Available: http://www.eetaa.gr/enimeroseis/17-01-13/Note_CCRE_Dexia_EN.pdf(13 May, 2014)

Dabla-Noris, E. (2006). The Challenge of Fiscal Decentralization in Transition Countries. Comparative Economic Studies, 48:100-131. http://dx.doi.org/10.1057/palgrave.ces.8100063

Dabla-Noris, E. and Wade,P. (2002). The Challenge of Fiscal Decentralization in Transition Countries. IMF Working Papers. WP/02/103. http://dx.doi.org/10.5089/9781451852707.001

European Commission, Taxation trends in EU. 2012 Edition. Luxembourg 2012. [Online] Available: http://epp.eurostat.ec.europa.eu/ cache/ITY_OFFPUB/KS-DU-12-001/EN/KS-DU-12-001-EN.PDF

Gamkhar, S. and Shah, A. (2007).The Impact of Intergovernmental Fiscal Transfers: A Synthesis of the Conceptual and Empirical Literature. In A.,Shah\&R. Boadway (Eds.), Intergovernmental Fiscal Transfers: Principles and Practice (pp.225-258). Public Sector Governance and Accountability Series. World Bank.

Ivanov, S. (1999). Local finance. NAMBR, Sofia.

Martinez-Vazquez, J. (2001). Intergovernmental Fiscal Relations and the Assignments of Expenditure Responsibilities. Andrew Young School of Policy Studies. Georgia State University

McCullough,J.S., Savov,E. and Ivanov,S. (2003) Mid-course Review of Fiscal Decentralization: the Unfinished Agenda. RTI International. [Online] Available: http://www.rti.org/pubs/Mid-Course_Review_of_Fiscal_Decentralization.pdf(14March, 2014)

Ministry of Finance of the Republic of Bulgaria. (2013). Annual report on the state budget execution, 2012. [Online] Available: http://www.minfin.bg/bg/page/690(08 (13 April, 2014) 
National Association of Municipalities in the Republic of Bulgaria. (2014).Analysis and assessment of municipal budgets in 2013. NAMRB, Sofia.

Nikolova,D.,Cvetkov,A.,Ganev,P., Alexiev, J. and Valakanov,N. (2013) . Regional Profiles: Indicators of Development. Institute for Market Economy. [Online] Available: http://www.regionalprofiles.bg/var/docs/Editions/Regional_Profiles_2013_BG.pdf(23March, 2014)

Oliveira, J and Martinez-Vazquez, J. (2001). Czech Republic: Intergovernmental fiscal relations in the transition. World Bank: Washington. http://dx.doi.org/10.1596/0-8213-5043-9

Rodriguez-Pose, A. and Kroijer, A. (2009). Fiscal Decentralization and Economic Growth in Central and Eastern Europe. Growth and Change, 40 (3):387-417 http://dx.doi.org/10.1111/j.1468-2257.2009.00488.x

Shah, A. (1991). Perspectives on the Design of Intergovernmental Fiscal Relations, The World Bank Policy Research Working Paper Series, 726, Washington DC: The World Bank.

Shah, A. (1994). The Reform of Intergovernmental Fiscal Relations in Developing and Emerging Market Economies. Washington DC: World Bank. http://dx.doi.org/10.1596/0-8213-2836-0

Tanzi, V. (2001). Pitfalls on the Road to Fiscal Decentralisation. CEIP Working Paper No. 19. CEIP, Washington, D.C.

Wetzel, D. (2002). Decentralization in the Transition Economies: Challenges and the Road Ahead. Washington, DC: World Bank. 